\title{
The Effect of Playing Bridge Beams on the Coordination and Balance of the Body of Early Childhood
}

\author{
Hafidzah Amelia1,a, ${ }^{*}$, Hendratno1,b, Miftakhul Jannah',c \\ 1Postgraduate of Basic Education, Surabaya State University, East Java, 60213, Indonesia \\ Jl. Rektorat Unesa, Lidah Wetan Kecamatan Lakarsantri Surabaya, East Java, 60213, Indonesia \\ a* hafidzah.17070855050@mhs.unesa.ac.id; b hendratno@unesa.ac.id; c miftakhuljannah@unesa.ac.id \\ ${ }^{*}$ Corresponding Author: \\ Whatsapp Number [08985321670]
}

How to Cite: Amelia, H., Hendratno, H., \& Jannah, M. (2019). The Effect of Playing Bridge Beams on the Coordination and Balance of the Body of Early Childhood. International Journal for Educational and Vocational Studies, 1(1), 72-74. DOI: https://doi.org/10.29103/ijevs.v1i1.1499

\section{ARTICLE HISTORY}

Received: 22 March 2019

Revised: 28 April 2019

Accepted: 29 May 2019

\section{KEYWORDS}

Playing the Bridge Beams Coordination and Balance Body of Early Childhood

\section{ABSTRACT}

This study aims to determine the effect of playing bridge beams on the coordination and balance of the body of children aged $5-6$ years. The research subjects were children aged $5-6$ years in Raudhatul Athfal (Kindergarten School) Munawwarus Sholeh of Situbondo district. The research approach used is a quantitative approach with a quasi-experimental design. Research data was obtained through tests given to children and documentation taken at the time of the study. Data analysis techniques in this study using independent sample t-test. The results of the data analysis show the number sig. $0,000>0,050$, it shows that the null hypothesis is rejected so that it can be concluded that there is the influence of playing the bridge beams on the coordination and balance of the body of children aged 5-6 years.

\section{INTRODUCTION}

The most important period of human life is the first six years of a child's life (Hasibuan, 2017). The period is known as the golden age (golden-age) in human development because the development of intelligence at this time experienced a very significant increase. Therefore, there is a need for special assistance for early childhood to optimally stimulate every scope of development that children have so that the golden age is not missed in vain.

One scope of development that is very important to be stimulated optimally at an early age is motor development. According to Allen (2010), motor development is the child's ability to move and control parts of his body. These aspects of development greatly determine the smooth learning, both in the field of knowledge (cognitive), skills (psychomotor) and attitudes (affective) (Mulyasa, 2012). Also, Sun (2010) argues that the development of motor skills is very important for children because cognitive learning is based on the sensitivity of movement. Libertus (2013) emphasizes that children's initial motor skills are very important for language, social, and cognitive development. Motor skills involve knowledge about how to complete tasks and when to do it to achieve completion (Hsiao, 2015). This makes motor skills very necessary to be stimulated optimally from an early age in order to be able to support the development of other aspects.
There are two kinds of motor development, namely, gross motor and fine motor (Sujarwo, 2015). Gross motoric activity is the activity of large muscles, such as crawling, walking, running, etc. While the fine motor is an activity that involves the movement of small muscles, such as taking small objects using the thumb and index finger, writing, moving the fingers, and so on.

Gross motor development is very dependent on aspects of children's physical fitness (Ministry of National Education, 2008). Physical fitness is divided into several components, including balance, coordination, speed, strength, agility, reaction speed, lung heart resistance (cardio-respiration), muscle strength, muscle endurance, and flexibility (Widiastuti, 2015). All of these components need to be trained for early childhood so that the child's body becomes healthy, is not susceptible to disease, and is not easily tired of learning and other activities.

The wider problem of balance and motor coordination affects a person's ability to participate in physical activity and exercise. Balance problems can also cause an increased risk of morbidity associated with a lack of physical activity and exercise, such as obesity which is a growing public health problem (Okuda, 2018). 
Allen (2010) states that playing bridge beam can be used to stimulate the gross motoric skills of children aged 5-6 years, especially the components of balance and coordination. In line with Sawer (2015) and Uematsu (2018), both of them stimulate the body's balance using beam walking. Beam walking is used to test the effects of age in terms of walking balance, as well as physical control (physical) and increasing errors in motor learning (Sawer, 2015).

Based on the explanation above, the researchers felt the need to examine the game that can be used to improve the coordination and balance of the body of children aged 5-6 years, namely believing the bridge beams.

\section{Body Balance}

According to Moraru (2014), body balance is the body's ability to realize and control the body's posture in the air in order to maintain an orthostatic position in a state of silence and movement. There are two kinds of balance, namely, static balance and dynamic balance (Mackenzie, 2005). Static balance is the ability to maintain a balanced state of silence, while the dynamic balance is the ability to maintain a balanced state in a state of motion, for example, running, walking, soaring, etc. (Fenanlampir, 2015).

\section{Body Coordination}

Coordination, according to Fenanlampir (2015), is a very complex motor ability. Coordination is closely related to other physical fitness components, such as speed, strength, endurance, flexibility, agility, balance, and kinesthetic sense. So coordination is defined as the body's ability to coordinate the nervous system and muscles to make movements that are accurate, harmonious, and elegant (Hsiao, 2016). A child who has good coordination can do skills easily, quickly and perfectly. His skills can involve eye-foot coordination or eye-hand coordination.

\section{METHOD}

The research will be conducted using a quantitative research approach with the experimental method. The researcher gave treatment in the form of playing to walk the beams to improve the child's coordination and balance. The experimental design that will be used is Quasi-Experi mental design. The type of Quasi-Experimental used was the design of the Nonequivalent Control Group, in this design, measurements were taken on pretest and posttest in the experimental group and the control group (Jannah, 2016). This research began on 13 to 23 April 2019, which was held at RA Munawwarus Sholeh Situbondo in the academic year 2018/2019.

The population in this study were children aged 5-6 years or group B. The study sample was group B2, which numbered 15 children as the experimental group, and group B1 with a total of 15 children as the control group. The following research design will be carried out:
Table 1. Quasi-Experimental: Nonequivalent Control Group Design

\begin{tabular}{cccc}
\hline Group & Before & Treatment & After \\
\hline Experiment & $\mathrm{O}^{1}$ & $\mathrm{X}$ & $\mathrm{O}^{2}$ \\
\hline Control & $\mathrm{O}^{2}$ & - & $\mathrm{O}^{2}$ \\
\hline
\end{tabular}

Based on the design scheme above, researchers develop into a research model that can be seen in the following figure.

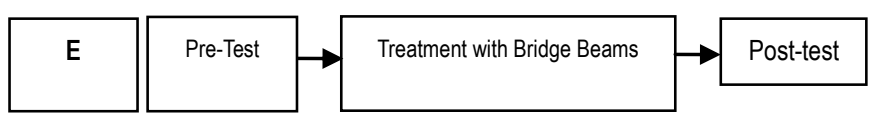

Figure 1. The Experimental Group Research Model

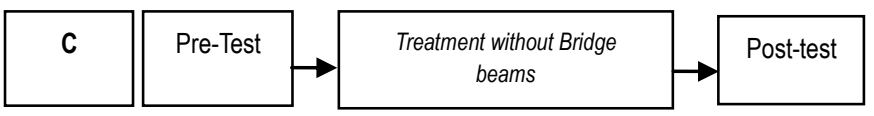

Figure 2. The Control Group Research Model

The independent variable in this study is playing the bridge beam, and there are two dependent variables, namely coordination, and balance of the body. To measure body coordination tests are carried out kicking and throwing the ball at the target (Ulrich, 2000), while to measure the body balance of the child a standing test is performed on one leg (Oberer, 2017). The instrument used in this study is based on the standard level of achievement of early childhood development listed in the standard of early childhood education (Minister of Education and Culture of the Republic of Indonesia, No. 137 of 2014). Analysis of research data using the help of the SPSS 25 Software, namely the independent sample T-test. Before the different test, a prerequisite test was carried out, namely the normality test and homogeneity test.

\section{RESULTS AND DISCUSSION}

Test the validity of the instrument in this study was carried out by consulting the instrument on the experts of the problem under study (judgment experts)-test reliability using the alpha Cronbach test. The following are the results of the instrument reliability test.

Table 2. Instrument of Reliability Test Results

\begin{tabular}{cc}
\hline Cronbach's alpha & Number of Indicators \\
\hline 0,898 & 6 \\
\hline
\end{tabular}

Table 2 shows the results of the research instrument reliability test of 0.898 . This value is greater than 0.8 , so the research instrument is declared reliable. The results of the pre-test and post-test in the control and experiment groups can be seen in table 3 .

Based on the research data in table 3 , it can be seen that in the control group there was no significant increase between pretest and posttest, while in the experimental group, there were significant changes between pretest and - 
posttest in coordination and balance. This identifies the influence of playing the bridge beam on the child's body coordination and balance.

Table 3. Data of Research Results

\begin{tabular}{|c|c|c|c|c|c|c|}
\hline Group & Variable & Test & Average & $\begin{array}{c}\text { Max } \\
\text { Value }\end{array}$ & Min Value & $\begin{array}{c}\text { Stad. } \\
\text { Deviation }\end{array}$ \\
\hline \multirow{4}{*}{ Control } & \multirow{2}{*}{ Coordination } & Pre- & 3,330 & 5,000 & 2,000 & 1,047 \\
\hline & & Post- & 3,270 & 5,000 & 2,000 & 1,033 \\
\hline & \multirow{2}{*}{ Balance } & Pre- & 6,330 & 9,000 & 4,000 & 1,589 \\
\hline & & Post- & 6,800 & 10,000 & 4,000 & 1,612 \\
\hline \multirow{4}{*}{ Experiment } & \multirow{2}{*}{ Coordination } & Pre- & 3,200 & 5,000 & 2,000 & 1,082 \\
\hline & & Post- & 5,000 & 7,000 & 3,000 & 1,309 \\
\hline & \multirow{2}{*}{ Balance } & Pre- & 7,000 & 10,000 & 4,000 & 1,927 \\
\hline & & Post- & 5,000 & 7,000 & 3,000 & 1,309 \\
\hline
\end{tabular}

The following are the results of the analysis of different tests of coordination and balance abilities.

Table 4. Results of Different of Test Analysis

\begin{tabular}{lcccc}
\hline \multirow{2}{*}{ Variable } & Test & $\begin{array}{c}\text { Sig. } \\
\text { (2-tailed) }\end{array}$ & $a$ & Conclusion \\
\hline \multirow{2}{*}{ Coordination } & Pre- & 0,734 & 0,05 & $\mathrm{H}_{0}$ Received \\
\cline { 2 - 5 } Balance & Post- & 0,000 & 0,05 & $\mathrm{H}_{0}$ Reject \\
\cline { 2 - 5 } & Pre- & 0,310 & 0,05 & $\mathrm{H}_{0}$ Received \\
\cline { 2 - 5 } & Post- & 0,000 & 0,05 & $\mathrm{H}_{0}$ Reject \\
\hline
\end{tabular}

Based on table 4 above, it can be seen that the value of Sig. (2-tailed) On coordination and balance pretest greater than a value, so that it can be stated that $\mathrm{H}_{0}$ is accepted which means there is no difference between coordination/ balance ability in the control and experimental groups. While the level of sig. (2-tailed) in the posttest data smaller than $a, 0,000<0,05$, so that it can be stated that $\mathrm{H}_{0}$ is rejected, which means there is a difference between the control group and the experimental group.

The playground of the pedestrian beam that has been implemented in RA Munawwarus Sholeh's children, namely children aged 5-6 years, influences the child's body coordination. This is in Haugen's opinion (2018), which states that playing the bridge provides an opportunity for children to practice coordination. When climbing the beams of the eyes, feet, hands, and body are required to coordinate so that they can walk well to the end of the bridge without falling, so that by playing the beams directly the child's coordination ability is stimulated. The more often the child does this activity, the better the coordination of the entire child's body.

This activity also influences the child's body balance. This is following the opinion of Sawers (2015), which states that playing bridge beam provides an opportunity for children to train their body balance. When climbing the bridge, the child is required to be able to maintain his position against gravity so that the child does not fall from the bridge beams.

\section{CONCLUSION}

Based on the results of the study, it can be concluded that playing the bridge influences the coordination and balance of the body of children aged 5-6 years.

\section{REFERENCES}

Allen \& Marotz. (2010). Profil Perkembangan Anak. (Valentino, Penerjemah). Jakarta: PT. Index

Departemen Pendidikan Nasional. (2008). Pengembangan Kemampuan Motorik Kasar di Taman Kanak-Kanak. Direktorat Pembinaan Taman Kanak-kanak dan Sekolah Dasar

Fenanlampir, A. \& Faruq, M. M. (2015). Tes dan Pengukuran Dalam Olahraga. Yogyakarta: CV Andi Offset

Hasibuan, Rachma. (2017). Perencanaan Pembelajaran PAUD. Surabaya: Unesa University Press

Haugen, T \& Johansen, B. T. (2018). The difference in physical fitness in children with initially high and low gross motor competence: a ten-year follow-up study. Journal of Human Movement Science, 62, 143 - 149. doi:10.1016/j.humov.2018.10.007

Hsiao, H. S. \& Chen, J. C. (2016). Using a gesture interactive game-based learning approach to preschool children's learning performance and motor skills. Journal of computers \& education, 95 (2016) 151-162

Hsiao, H. S., Chen, J. C., \& Hong, K. (2015). Building the vocational phase of the computerized motor skills testing system for use in the electronics and electrical engineering group and hospitality group. Journal of interactive learning environments, 1744-5191

Jannah, M. (2016). Psikologi Eksperimen, Sebuah Pengantar. Surabaya: UNESA University Press

Libertus, K \& Landa, R. J. (2013). The Early Motor Questionnaire (EMQ): a parental report measure of early motor development. Journal of Infant Behavior and Development, 36 (2013) 833-842

Mackenzie, B. (2005). 101 Performance evaluation tests. London: Electric Word plc

Moraru, C., Necules, M., \& Hodorca, R. M. (2014). Comparative study on the balance ability in sporty and unsporty children. Journal of Procedia Social and Behavioral Sciences, 116 (2014) 3659-3663

Mulyasa, H.E. (2012). Menejemen PAUD. Bandung: PT. Remaja Rosdakarya

Oberer, N., Gashaj, Venera, \& Roebers, C. M. (2017). Motor skills in kindergarten: internal structure, cognitive correlates, and relationships to Backround variables. Journal of Human Movement Sciences, 52 (2017) 170-180

Okuda, P. M. M., Swardfager, W., Ploubidis, G. B., Pangelinan, M., \& Cogo-Moreira, H. (2018). Influence of Birthweight on childhood balance: Evidance from two British birth cohorts. Journal of Early Human Development, 0378-3782

Peraturan Menteri Pendidikan dan Kebudayaan RI. No. 137 Tahun 2014. Standard Nasional Pendidikan Anak Usia Dini

Sawers, A. \& Ting, L. H. (2015). Beam walking can detect differences in walking balance proficiency across a range of sensorimotor abilities. Journal of Gait \& Posture 4391.No.5

Sujarwo \& Widi, C. P. (2015). Kemampuan Motorik Kasar dan Halus Anak Usia 4-6 Tahun, Jurnal Pendidikan Jasmani Indonesia, vol. 11 no. 2

Sun, S. H.,et al., (2010). Development and initial validation of the preschooler gross motor quality scale, Journal of Research in Development Disabilities 31 (2010) 1187-1196

Uematsu, A., Tsuchiya, K., Suzuki, S., \& Hortobágyi, T. (2018). Cognitive dual-tasking augments age-differences in dynamic balance quantified by beam walking distance: a pilot study. Journal of Experimental Gerontology,114, 27-31. doi.org/10.1016/j.exger.2018.10.016

Ulrich, D. A., (2000). Test of Gross Motor Development (2nd ed). Austin, TX: Pro-ED

Widiastuti. (2017). Tes dan Pengukuran Olahraga. Jakarta: PT Raja Grafindo Persada 